\title{
Habitat use and population structure of the invasive red swamp crayfish Procambarus clarkii (Girard, 1852) in a protected area in northern Italy
}

\author{
Roberta Donato ${ }^{1}$, Marta Rollandin ${ }^{1}$, Livio Favaro ${ }^{1}$, Alessio Ferrarese ${ }^{2}$, Daniela Pessani ${ }^{1}$ and \\ Daniela Ghia ${ }^{3, *}$ \\ ${ }^{1}$ Dipartimento di Scienze della Vita e Biologia dei Sistemi, Università degli Studi di Torino, via Accademia Albertina, 13, 10123 Torino, Italy \\ 2 Vivere i Parchi A.P.S, via Giovanni XXIII, 24, 10015 Ivrea, Italy \\ ${ }^{3}$ Dipartimento di Scienze della Terra e dell'Ambiente, Università degli Studi di Pavia, viale Taramelli, 24, 27100 Pavia, Italy
}

\begin{abstract}
The red swamp crayfish Procambarus clarkii is one of the most invasive alien species in Europe and included in the list of invasive species of Union concern. We describe for the first time some life-history traits of a red swamp crayfish population in the Nature Reserve of the Lago di Candia (Italy). We investigated(1) preferences of this species for specific environmental features on the banks of the lake, and (2) differences in size, sex ratio, and condition index between individuals caught in lake and marsh. Moreover, we compared sampling effort and the features of individuals caught in the lake, for two sampling seasons in 2014 and 2015. Findings indicated that the population was well established, and the marsh seemed to have better conditions for growth of individuals than the lake. Accordingly, continuity of riparian vegetation, opportunity to dig burrows, and trophic resource availability seems to facilitate the proliferation of the crayfish in the lake. Our study demonstrated that massive removal efforts over the whole active period of the species and more than one year of trapping are necessary to increase the controlling activities' success. This study could have important implications for further population management projects directed at biodiversity conservation in the area.
\end{abstract}

Keywords: Invasive alien species / Fulton's Condition Factor / microhabitat / lentic ecosystems / nature reserve / Piedmont

Résumé - Utilisation de l'habitat et structure des populations d'écrevisse de Louisiane envahissante Procambarus clarkii (Girard, 1852) dans une zone protégée du nord de l'Italie. L'écrevisse de Louisiane Procambarus clarkii est l'une des espèces exotiques les plus envahissantes d'Europe et figure sur la liste des espèces envahissantes préoccupantes de l'Union. Nous décrivons pour la première fois quelques traits de l'histoire de vie d'une population de l'écrevisse de Louisiane dans la Réserve Naturelle du Lago di Candia (Italie). Nous avons étudié (1) les préférences de cette espèce pour des caractéristiques environnementales particulières sur les rives du lac et (2) les différences de taille, de sex-ratio et d'indice de condition entre les individus capturés dans le lac et le marais. De plus, nous avons comparé l'effort d'échantillonnage et les caractéristiques des individus capturés dans le lac pour deux saisons d'échantillonnage en 2014 et 2015. Les résultats indiquent que la population est bien établie et que le marais semble avoir de meilleures conditions que le lac pour la croissance des individus. Par conséquent, la continuité de la végétation littorale, la possibilité de creuser des terriers et la disponibilité de ressources trophiques semblent faciliter la prolifération des écrevisses dans le lac. Notre étude a démontré que des efforts massifs d'enlèvement sur toute la période active de l'espèce et pendant plus d'un an de piégeage sont nécessaires pour accroître le succès des activités de contrôle. Cette étude pourrait avoir des implications importantes pour d'autres projets de gestion des populations axés sur la conservation de la biodiversité dans la région.

Mots-clés : Espèces exotiques envahissantes / Indice de Condition de Fulton / microhabitat / écosystèmes lentiques / réserve naturelle / Piémont

\footnotetext{
*Corresponding author: daniela.ghia@unipv.it
} 


\section{Introduction}

The native range of the red swamp crayfish Procambarus clarkii (Girard, 1852) is north-eastern Mexico and southcentral USA (Hobbs, 1972). This species has been successfully introduced for aquaculture in many other American states, and also in several other countries in South America, Asia, Africa and Europe (Huner, 2002). It can be now found in all continents except Australia and Antarctica (Huner, 1977; Huner and Avault, 1979). In Europe, P. clarkii was first introduced in the Guadalquivir river basin (Spain) in 1974. In only six years the species caused significant damage to the rice fields of the region and it was soon considered an agricultural pest (Adão and Marques, 1993). Procambarus clarkii was also introduced in Italy for commercial exploitation and spread in the wild at the beginning of $1990 \mathrm{~s}$, probably escaping from two different aquaculture facilities in Piedmont and Tuscany (Mazzoni et al., 2004). Procambarus clarkii has the $r$-selected features with rapid growth rates (Scalici and Gherardi, 2007) and highly plastic life cycle (Gutiérrez-Yurrita et al., 1999) typical of an invasive species. Its invasiveness may be increased by its overland spreading potential, thanks to its desiccation resistance (Banha and Anastácio, 2014) and capability to cover long distances out of water, relying on aerial respiration (Gherardi and Barbaresi, 2000; Favaro et al., 2011a).

Procambarus clarkii is included among the ' 100 of the worst' invasive aliens in Europe (DAISIE, 2017) and in the list of invasive alien species of Union concern (EU 2016/1141) for which effective management measures are required, as it meets the criteria listed in Art. No. 4 of EU Regulation 1143/2014. The species can affect water quality of invaded ecosystems by modifying water properties such as turbidity and dissolved oxygen (Souty-Grosset et al., 2016) as a result of its intense burrowing activity. Indeed, $P$. clarkii dig burrows in banks to cope with hostile environmental conditions like long-term droughts (Kouba et al., 2016), and to create shelters during the sensitive period of their life cycle (Gherardi, 2006), activity that can also damage dams, levees, and irrigation structures (Correia and Ferreira, 1995). Once introduced, P. clarkii may also disturb macrophytes and macroinvertebrate communities (Souty-Grosset et al.,2016) and it has negative effects on other animals, such as amphibians (Gherardi et al., 2001; Renai and Gherardi, 2004), fish (Ilhéu et al., 2007) and the native whiteclawed crayfish, Austropotamobius pallipes (Lereboullet, 1858) (Gherardi and Cioni, 2004; Favaro et al., 2010; Tirelli et al., 2011; Favaro et al., 2011b). Finally, P. clarkii can act as a vector of disease, as it may carry the oomycete Aphanomyces astaci Schikora, 1906 responsible for the crayfish plague which is lethal to native European crayfish populations (SoutyGrosset et al., 2016).

The first observations of $P$. clarkii in the Nature Reserve of the Lago di Candia (north-western Italy) occurred in 2011 (Delmastro, 2017). Since then, the area has been rapidly colonized by this species and specimens of $P$. clarkii can be easily seen walking underwater or overland, both in the lake and in the nearby marsh area. The aims of this study were to describe, for the first time, the habitat use, spatial distribution, size and sex ratio of the $P$. clarkii population established in the Nature Reserve of the Lago di Candia, by assessing the population within five years since the first observation and comparing the presence of $P$. clarkii in the lake and the marsh

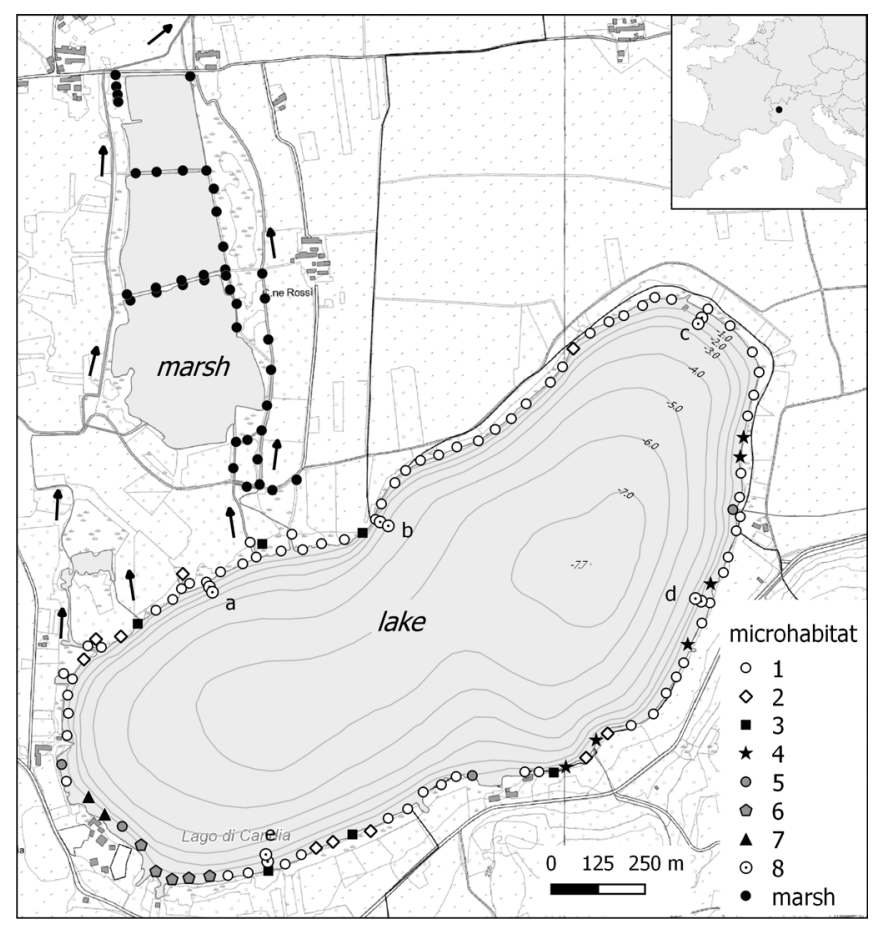

Fig. 1. Location of the study areas (lake and marsh), with sampling points labelled according to microhabitat categories (see Tab. 1). Arrows represent the direction of flow; ' $\mathrm{a}-\mathrm{e}$ ' represent linear transects.

areas in two consecutive years. Results from this study are discussed in the context of new EU regulations and should allow for the implementation of required management actions to limit its spread to potentially suitable nearby habitats.

\section{Materials and methods}

\subsection{Study area}

The study was conducted in the Nature Reserve of the Lago di Candia, north-western Italy (Fig. 1), a protected area included in the European "Natura 2000" Network, which is considered both a Site of Community Importance (SCI, IT1110036) according to the Habitats Directive (92/43/EEC), and a Special Protection Area (SPA) according to the Birds Directive (2009/147/EC). The Reserve has a surface area of $3.35 \mathrm{~km}^{2}$ and includes two different wetlands, a glacial lake and a marsh, which are connected through a channel system that allows water to flow from the northern bank of the lake to the marsh (Fig. 1). Outgoing water from the marsh is then collected by a ditch that flows into the Dora Baltea river (Po river basin). The lake has an area of $1.52 \mathrm{~km}^{2}$, a perimeter of $5.5 \mathrm{~km}$ and maximum depth of $7.7 \mathrm{~m}$. The banks have continuous cover of riparian vegetation. Water temperature was measured in the lake on all sampling days at 10:00, and it ranged from 22.1 to $27.8^{\circ} \mathrm{C}$ (mean $24.8^{\circ} \mathrm{C}$ ) in July-October 2014 and from 21.6 to $31.7^{\circ} \mathrm{C}$ (mean $26.4^{\circ} \mathrm{C}$ ) in JulySeptember 2015. The marsh has an area of $0.4 \mathrm{~km}^{2}$, consists of channels and areas with shallow water (less than $0.70 \mathrm{~m}$ ), and hosts a variety of riparian and aquatic plant species. The Lago di Candia is characterized by small bodies of water and 
Table 1. Microhabitat categories features and corresponding number of sampling traps.

\begin{tabular}{lllll}
\hline Microhabitat category & Riparian and aquatic vegetation species & Dominant category of lake bottom & Bank alteration (0-2) & $N$ of traps \\
\hline 1 & Phragmites australis, Thelypteris palustris & muddy & 0 & 70 \\
2 & Phragmites australis, Thelypteris palustris, & muddy & 0 & 10 \\
& Alnus glutinosa, Rubus ulmifollius & & 1 & 6 \\
3 & Alnus glutinosa, Salix caprea & muddy and pebbly & 1 & 7 \\
4 & Phragmites australis, Nuphar lutea & muddy & 2 & 4 \\
5 & / & pebbly or artificial & 2 & 5 \\
6 & Phragmites australis, Nelumbo nucifera, & pebbly and sandy & 2 & 2 \\
7 & Salix spp., Alnus glutinosa & pebbly and sandy & 0 & 10 \\
\hline
\end{tabular}

wetlands created by ancient glacial activities and connected by rivers, small streams, and irrigation ditches.

The most abundant macrophyte species that can be found in the lake are Najas marina, Nymphoides peltata, Trapa natans, Myriophyllum spicatum. The site is of great importance for more than 200 bird species, amphibians (Bufo bufo, Rana dalmatina), reptiles (Hierophis viridiflavus, Natrix natrix), and fish (Esox lucius). Moreover, in the protected area, also potential predators on different sizes of $P$. clarkii (Correia, 2001) can be found. These include several introduced fish species, such as Ictalurus melas, Lepomis gibbosus, and Micropterus salmoides.

\subsection{Crayfish sampling}

The field activities were carried out during seven weeks from 15th July to 10th October 2014 in both the lake and marsh, and three more times in the marsh until 21st October 2014; and during three weeks from 21st July to 24th September 2015 only in the lake. Volunteer Ecological Guards of the Nature Reserve were trained and involved in sampling activities. All the sampling points were georeferenced with a GPS (Global Positioning System) receiver (GARMIN62stc). In 2014, 104 sampling points, at a distance of $1 \mathrm{~m}$ from the bank, were investigated along the entire perimeter of the lake. The total number of captures, sorted by sex, was registered at each sampling point.

Crayfish were sampled using baited, cylindrical traps (90 cm long, mesh size $1 \mathrm{~cm}$, cross-section $30 \mathrm{~cm}$, and two access funnels $10 \mathrm{~cm}$ in diameter). The bait consisted of wet cat food (100 g each). During each sampling week, trapping was performed over 4 sequential nights, and traps were checked, emptied and re-baited daily. All crayfish collected were removed from the environment and suppressed by hypothermia. Consequently, crayfish were sexed, measured on cephalothorax length (CTL; from the tip of the rostrum to the cephalothorax posterior portion) by using a $0.1 \mathrm{~mm}$ precision calliper, weighted by using a $0.01 \mathrm{~g}$ precision digital scale. Finally, the specimens were disposed of in cooperation with the health government body Istituto Zooprofilattico Sperimentale del Piemonte, Liguria e Valle d'Aosta (S.S. Laboratorio Specialistico Ittiopatologia), and according to the Italian laws.
The Fulton's Condition Factor (FCF; Ricker, 1975) is a condition index calculated for every individual and it was obtained using the following formula: $\mathrm{FCF}=$ weight $/(\mathrm{CTL})^{3}$. All crayfish with missing or regenerating chelae were excluded from the FCF analysis.

Catch per unit effort (CPUE) was calculated for the three sets of samples (lake 2014, marsh 2014 and lake 2015) as the daily number of crayfish collected/number of traps. For each sampling week, CPUE was calculated as the mean of the daily CPUE.

\subsection{Microhabitat category identification}

To describe habitat use, the following microhabitat parameters were recorded at each sampling point: riparian and aquatic vegetation species, dominant typology of the lake bottom, and level of bank alterations by human activity. For the last parameter, we assigned an alteration value from 0 (absence of alteration) to 2 (intense alteration due to business, for example restaurant, with cut grass). Ten additional sampling points were selected along five linear transects perpendicular to the banks (transects 'a-e', at $25 \mathrm{~m}$ and at $50 \mathrm{~m}$ ) to investigate the presence of $P$. clarkii at greater depths (mean $-1.3 \pm 0.86 \mathrm{~m}$ deep at $25 \mathrm{~m}$ from the bank; mean $-2.4 \pm 0.83 \mathrm{~m}$ deep at $50 \mathrm{~m}$ from the bank). Consequently, eight different microhabitat categories were identified (from 1 to 8 ) based on the parameters observed (Tab. 1). Finally, each sampling point was assigned to one of these categories (every category includes, therefore, a different amount of sampling sites). In 2014, sampling sessions at 40 sites in the channels of the marsh area were also carried out. In 2015 in the lake, 26 sampling points were selected from the 104 of the previous year.

\subsection{Statistical analyses}

Non-parametric statistical tests were carried out because the data did not meet the requirement for normal distribution, even after log-transformation (Sokal and Rohlf, 1995). Because data violated the assumption of homogeneity of variances (Levene's test: $P<0.001$ ), but were robust for skewed distributions and large sample sizes (Fagerland, 2012), Welch's ANOVA with post-hoc multiple comparisons was used to evaluate differences in the collected daily biomass (mean crayfish weight collected per trap) in the different microhabitat 


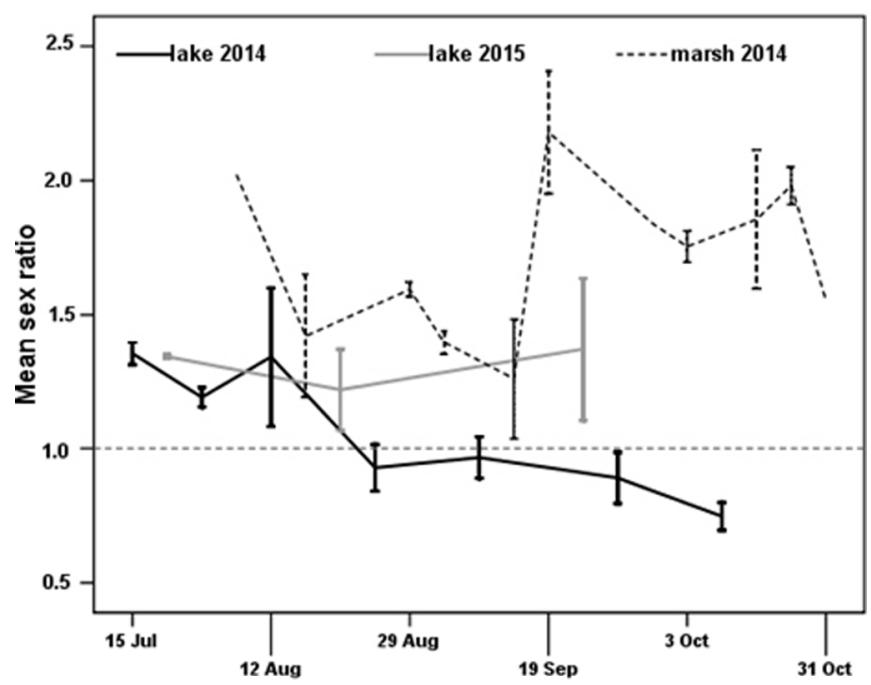

Fig. 2. Mean sex ratio values (males/females) obtained in each sampling week, divided per habitat and per year. Reference dotted line to 1 shows the expected 1:1 balance. Error bars: \pm SE.

categories. A Spearman's Rho test and a Chi-squared test $\left(\chi^{2}\right)$ were used to investigate the correlation and the presence of the species at different water depths in the lake. A Chi-squared test was also used to assess the sex ratio balance within the three sets of samples (lake 2014, marsh 2014, lake 2015). A Spearman's Rho test allowed us to investigate any correlation between CTL and weight of individuals in both sexes. Finally, Mann-Whitney U tests were used to assess differences in size between individuals caught in the marsh and in the lake in 2014, differences among the calculated Fulton's Condition Factor values of the three sets of samples (lake 2014 vs. marsh 2014 and lake $2014 v s$. lake 2015), and to assess the difference in the total number of captures in the lake between the two years (2014 and 2015). Statistical differences were detected with a level of significance $P<0.05$ and all statistical analyses were performed using SPSS 22.0 (Statistical Package for the Social Sciences, SPSS Inc.).

\section{Results}

\subsection{Samples features}

A total sample of 19,971 individuals (9983 males and 9988 females) was collected in the lake in 2014 and 6073 individuals (3787 males and 2286 females) were collected in the marsh in the same year. In addition, 2634 crayfish (1461 males and 1173 females) were caught in the lake in 2015. These three sets of samples showed significant differences from the expected sex ratio 1:1 within each sampling period (Chi-squared test after contingency table; lake 2014: $\chi^{2}=332.853, d f=25, P<0.001$; marsh 2014: $\chi^{2}=51.586, d f=18, P<0.001$; lake 2015: $\left.\chi^{2}=28.908, d f=11, P<0.005\right)$. In the sample collected in the lake in 2014, males were more abundant than females until the end of August, when a switch of the ratio was recorded and persisted until the end of the sampling activities (first ten days of October). On the other hand, in both the marsh 2014 sample and the lake 2015 sample, more males than females were collected during the entire sampling period (Fig. 2).

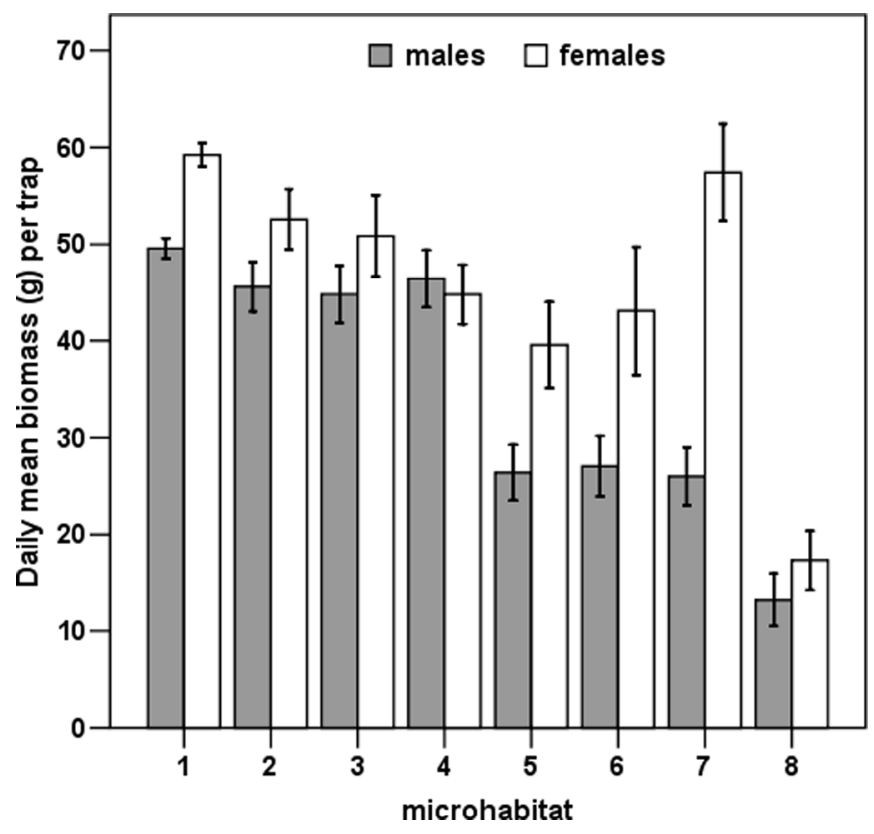

Fig. 3. Daily mean extracted biomass (g) per trap for each microhabitat category (from 1 to 8 ), divided per sex. Error bars: \pm SE.

\subsection{Habitat use}

Significant differences were shown in extracted biomass per trap among different microhabitat categories (Welch's ANOVA; $\left.F_{(7 ; 736.761)}=51.826, P<0.001\right)$, also considering males and females separately (Welch's ANOVA; males: $F_{(7 ; 376.034)}=35.182, P<0.001$; females: $F_{(7 ; 363.964)}=25.181$, $P<0.001)$. A clear preference was shown for category 1 , characterised by continuous vegetation cover on the bank (Phragmites australis and Thelypteris palustris), muddy and silty bottom and no physical alteration by human activity. On the contrary, categories 5 and 8 , characterized respectively by pebbly and deeper water, were the least frequented; moreover, in both categories, vegetation was absent. Category 7, typified only by the presence of Trapa natans, showed a preference peak by females, while it was not much frequented by males (Fig. 3). Consequently, the Dunnett's C post-hoc multiple comparisons pointed out the significant differences among microhabitats for both sexes (Tab. 2).

An inverse relationship between crayfish and depth of the lake was also observed both in terms of biomass (Spearman's Rho test; $\rho=-0.412, P<0.001$ ) and number of trapped crayfish (Spearman's Rho test; $\rho=-0.412$, $P<0.001)$.

\subsection{Catch Per Unit Effort}

For each sampling week, CPUE was calculated as a mean value of the daily CPUE (Fig. 4). Overall, CPUE values did not differ significantly between the three sampling periods (Kruskal-Wallis test: $\chi^{2}=1.473, d f=2, P>0.05$ ). Moreover, water temperature did not affect CPUE in the lake (Spearman's Rho test; $\rho=0.180, P>0.05$ ). 
Table 2. Dunnett's $\mathrm{C}$ post hoc multiple comparisons of mean difference between daily biomass (g) per trap for each microhabitat category (from 1 to 8 ) for females (above the diagonal) and males (below the diagonal). Bold type indicates results that were significant $(P<0.05$; in brackets, standard error).

\begin{tabular}{|c|c|c|c|c|c|c|c|c|}
\hline Microhabitat & 1 & 2 & 3 & 4 & 5 & 6 & 7 & 8 \\
\hline 1 & - & $6.7(3.36)$ & 8.4 (4.39) & $14.4(3.31)$ & $19.7(4.61)$ & $16.1(6.74)$ & $1.8(5.16)$ & $41.9(3.32)$ \\
\hline 2 & $4.0(2.78)$ & - & $1.7(5.25)$ & $7.8(4.39)$ & $13.0(5.44)$ & $9.5(7.38)$ & $4.8(5.91)$ & $\mathbf{3 5 . 3}(4.40)$ \\
\hline 3 & $4.8(3.17)$ & $0.8(3.93)$ & - & $6.1(5.22)$ & $11.3(6.13)$ & $7.8(7.86)$ & $6.5(6.55)$ & $33.6(5.23)$ \\
\hline 4 & $3.2(3.16)$ & $0.8(3.93)$ & $1.6(4.21)$ & - & $5.2(5.42)$ & $1.7(7.32)$ & $12.6(5.89)$ & $27.5(4.37)$ \\
\hline 5 & $23.2(3.07)$ & $19.2(3.86)$ & $18.4(4.15)$ & $\mathbf{2 0 . 0}(4.14)$ & - & 3.5 (7.99) & $17.8(6.71)$ & $22.3(5.42)$ \\
\hline 6 & $22.5(3.30)$ & $18.5(4.05)$ & $17.8(4.32)$ & $19.4(4.31)$ & $0.7(4.25)$ & - & $14.3(8.32)$ & $25.8(7.32)$ \\
\hline 7 & $23.6(3.20)$ & $19.6(3.96)$ & $18.8(4.24)$ & $20.4(4.24)$ & $0.4(4.17)$ & $1.0(4.35)$ & - & $40.1(5.90)$ \\
\hline 8 & $36.4(2.91)$ & $32.4(3.73)$ & $31.6(4.03)$ & $33.2(4.02)$ & $13.2(3.95)$ & $13.9(4.14)$ & $12.8(4.05)$ & - \\
\hline
\end{tabular}

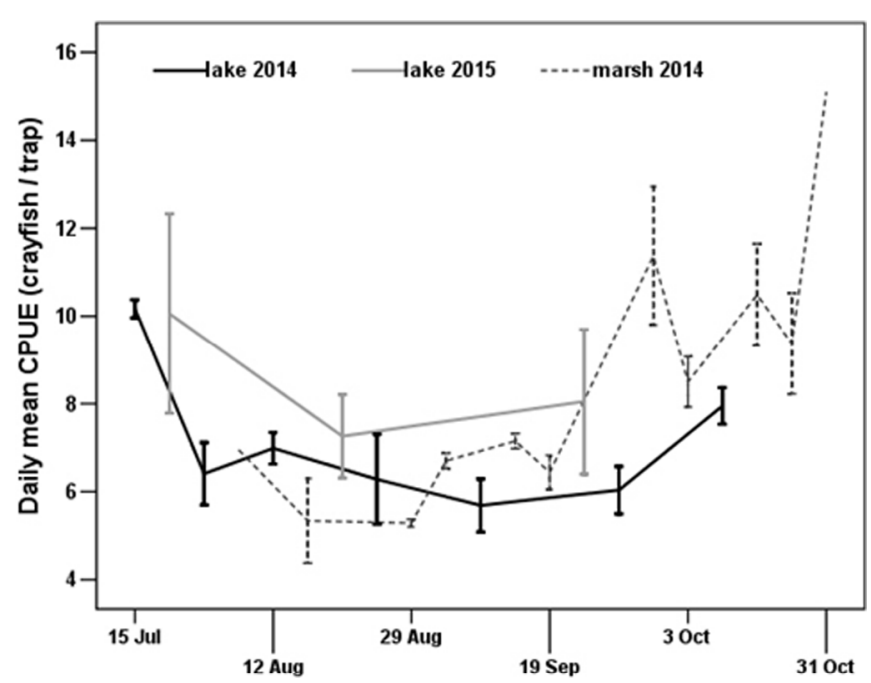

Fig. 4. Daily mean CPUE values, referred to sampling session, in the different habitats (marsh and lake) and years (2014 and 2015). Error bars: \pm SE.

\subsection{Comparison of crayfish size in lake vs. marsh habitats}

Values of CTL (Fig. 5) and FCF (Tab. 3) were used to carry out comparisons between the set of samples collected in the lake and in the marsh in 2014 in order to identify possible differences in the size and condition of crayfish living in the two habitats. CTL differences between males and females were significant in both habitats (Mann-Whitney test, lake: $U=43893403.0, \quad Z=-39.384, \quad P<0.001$; marsh: $U=1161867.5, Z=-8.298, P<0.001)$. Therefore, the test was performed on males and females separately and in both cases significant differences were found between habitats (Mann-Whitney U-test, males: $U=3635262.5, Z=-47.462$, $P<0.001$; females: $U=3414629.5, Z=-28.011, P<0.001$ ), with a larger crayfish size in the marsh than in the lake.

Comparisons between different habitats and different years were carried out on values of FCF for males and females separately, because males showed significantly higher FCF values than females (Mann-Whitney U-test, $U=10617867$, $Z=-39.558, P<0.001)$. For both sexes, the statistical analysis did not show any significant difference between crayfish collected in the lake and in the marsh in 2014 (Mann-Whitney U-test, males: $U=1245977.5, Z=-1.580, P>0.05$; females: $U=771939.5, Z=-1.228, P>0.05)$. On the contrary, the FCF values in both sexes were significantly different between crayfish caught in the lake in the two years (Mann-Whitney Utest, males: $U=2145065.5, Z=-9.217, P<0.001$; females: $U=1617983.5, Z=-5.039, P<0.001$ ), with higher FCF values registered in the samples collected in 2015.

\subsection{Comparison of captures in the two years}

Since the sampling effort was reduced in 2015 , only data from corresponding periods and sampling sites in the lake between the consecutive years were compared. The analysis thus involved 1861 individuals (955 males and 906 females) caught in 2014 and all crayfish caught in 2015 (2634 crayfish: 1461 males and 1173 females). Significantly more individuals were collected in 2015 compared to the previous year (after Mann-Whitney U test, $U=36652.5, Z=-5.351, P<0.001$ ). The difference was also significant considering all three months of activities separately, in each month more crayfish were caught in 2015 than in 2014 (after Mann-Whitney U test, July: $U=3932.5, Z=-3.407, P<0.001$; August: $U=4220.5$, $Z=-2.744, P<0.01$; September: $U=4054.0, Z=-3.127$, $P<0.005)$

\section{Discussion}

The present study describes - for the first time - the habitat use and population biology of the invasive $P$. clarkii in a wetland in north-western Italy. Our findings are supported by a large sample of crayfish collected from the two investigated habitats and over 2 consecutive years.

The sex ratio we observed during the sampling period in all the three sets of samples was different from the expected 1:1 balance usually found for cambarids (Reynolds, 2002). This is probably due to certain factors that can induce a difference in the activity of the two sexes (such as reproduction period, incubation period, and burrowing habit) throughout the year (Gherardi and Barbaresi, 2000; Gherardi et al., 2000; Gherardi et al., 2002). In particular, in 2014, we caught significantly more males than females in the lake, until the second half of August, when we observed a switch in this trend and significantly more females than males were sampled up to 
(a) females

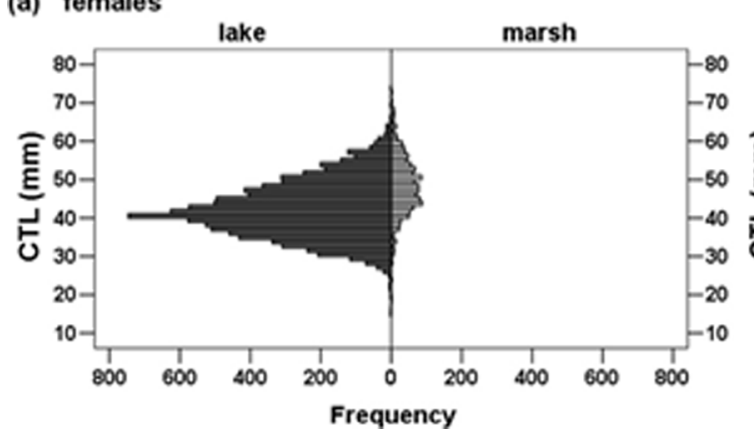

(b) males

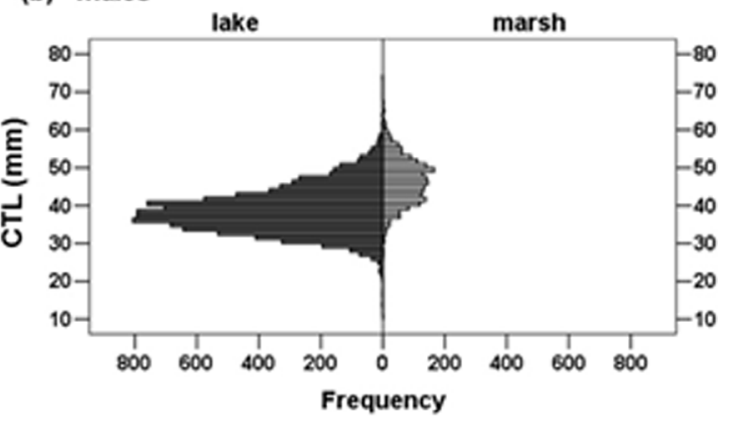

Fig. 5. Cephalothorax length (CTL; mm) frequencies in the two habitats, divided per sex: (a) females, (b) males.

early October. Instead, in the other two sets of samples (marsh 2014 and lake 2015), significantly more males than females were caught over the entire period. Examples of unbalanced sex ratios in different periods of the year have been frequently reported in the Italian populations of $P$. clarkii where either males outnumber females (Chiesa et al., 2006; Ligas, 2008; Dörr and Scalici, 2013; Maccarone et al., 2016) or vice versa (Ligas, 2008; Scalici et al., 2010). Moreover, P. clarkii females clearly outnumbered males both in Europe and in Africa (i.e. Oluoch, 1990; Anastácio and Marques, 1995; Fidalgo et al., 2001). In the original area of distribution (Louisiana), the ratio of females to males calculated throughout the year was approximately equal, even though there was a considerable decrease of females during the warmer months, due to their annual spawning cycle (Penn, 1943; Huner, 1978).

We suggest that the discrepancy in the sex ratio values observed in our study is linked to the reproductive activity of females during the summer months, which tend to remain in their burrows to provide parental care to their offspring (Vogt, 2013). Indeed, in the 2 years in the lake, both egg-bearing and egg-hatched females were rarely trapped and constituted only $1.1 \%$ and $1.7 \%$ of the females caught in 2014 and 2015 , respectively. We therefore presume that removal of 19,971 crayfish from the lake in 2014 could free environmental resources and space, and lead to the immigration of males from the marsh, where they outnumbered females in 2014.

Comparisons performed between the catches in the lake, during the corresponding periods of the 2 years, showed that more crayfish were collected in 2015 than in 2014, despite the remarkable sampling effort of 2014, when almost 20,000 individuals were caught and removed. Two main hypotheses could explain this result. Firstly, the massive catches carried out in 2014 were probably not sufficiently spread out throughout the year, as they affected only 4 consecutive months. Secondly, only 1 year of catches was probably not enough to reduce the abundance of a well-established crayfish population such as that found in the lake. Finally, continuous colonization of the lake by new individuals coming from adjacent areas (fields, irrigation systems, tree plantations) is hypothesised, as also suggested by Savini et al. (2008) in a Nature Reserve in northern Italy, and by Cruz and Rebelo (2007) in freshwater habitats of the southwest Iberian Peninsula. Indeed, $P$. clarkii is capable of high mobility and probably has good orientation skills as well (Breithaupt et al., 1995), especially during its "wandering phase" (a spatial strategy opposed to the "stationary phase"). This is a period of short peaks of high speed locomotion, which especially characterizes the behaviour of breeding males, and supports the dispersion of the species. For example, in the rice fields of the Lower Guadalquivir (Spain), crayfish during the "wandering phase" covered up to $17 \mathrm{~km}$ in 4 days, and an area of $20 \mathrm{~km}^{2}$ in the same time span (Gherardi and Barbaresi, 2000). The extent of dispersal and the speed of locomotion seem to differ between individuals, and could depend on the sex of crayfish, as well as environmental parameters and the life cycle period (Barbaresi et al., 2004). Moreover, P. clarkii is able to adapt quickly to different conditions due to its ecological plasticity and to spread local parasites and mycoflora on its carapace (Dörr et al., 2011, Dörr et al., 2012a, Dörr et al., 2012b; Chiesa et al., 2014; Bissattini et al., 2015).

Our results revealed significant differences in CTL between sexes in the lake and in the marsh, with females being larger than males in both habitats. In Lake Trasimeno (central Italy), based on total length measures, a previous study also found significant size differences in favour of females (Dörr et al., 2006). However, other studies performed in Italy did not reveal any significant differences between the size of males and females in the collected samples (Scalici and Gherardi, 2007; Scalici et al., 2010). As clutch size (i.e. fecundity) significantly increases with body size, females could be subjected to strong selective pressure to quickly reach a large size (Aquiloni and Gherardi, in Scalici and Gherardi, 2007).

Crayfish caught in the marsh were, on average, larger in CTL than those from the lake in the same year; this feature could be attributed to different factors. Crayfish growth rate is influenced by several factors, such as water temperature, light intensity, quantity and quality of nutrients, and population density (Aiken, 1980; Reynolds, 2002). The differences found in size could be related to a difference in the trophic resources present in the different habitats (Paglianti and Gherardi, 2004; Ramalho et al., 2008).

FCF values revealed a significant difference between sexes, with males showing higher values than females. This difference could be the result of a higher average size (and therefore weight) of the chelae in males than in females, confirming what was previously observed by Anastácio and Marques (1998), who calculated FCF by using post orbital carapace length instead of CTL. Lack of significant differences in the FCF values, calculated for individuals caught in the lake and in the marsh in 2014, revealed a homogeneous condition of the two populations for both males and females. However, in 
both sexes, crayfish collected from the lake in 2015 showed higher values of FCF than those collected in the previous year, indicating that in 2015 the species probably experienced better environmental conditions related to their ecological needs.

The habitat use study revealed that crayfish tended to frequent shallower waters and remain close to the banks, rather than inhabiting areas at a certain distance from the lake shore. Indeed, greater depths do not provide $P$. clarkii with certain environmental features that they require (e.g. food availability or the opportunity to shelter or burrow digging). As shown by other crayfish species like Procambarus alleni (Faxon, 1884), population density decreases with water depth and increases with plant biomass (Jordan et al., 1996). Thus, at greater depths, where macrophytes do not occur, crayfish can be consumed by large fish predators; plant biomass, conversely, reduces the danger of predation by birds and fish predators (Heck and Crowder, 1991). In addition, in the Lago di Candia, the species shows a minor preference for sites typified by discontinuity of riparian vegetation, pebbly bottom and physical banks altered by human activity that makes burrow digging impossible (features that, to varying degrees, contribute to describe microhabitat categories from 2 to 8). However, the lack of muddy banks does not seem to decrease the survival of $P$. clarkii (Aquiloni et al., 2005). Indeed, crayfish can also find shelter under boulders, and in crevices and vegetated sections of rivers and lakes. Moreover, males more frequently choose to hide under boulders while females, on the contrary, take refuge in complex microhabitats, such as pond sections vegetated by aquatic macrophytes (Aquiloni et al., 2005). Therefore, the habitat use evaluation demonstrated a high degree of suitability of the study area for colonization by crayfish. Indeed, the category 1 microhabitat, which is favoured by the species, covers more than $60 \%$ of the investigated sites. Moreover, 50 out of 70 sites belonging to category 1 were located along the northern lake shore, which is the area that links the lake with the marsh, through a web of channels.

In conclusion, we highlighted the presence of an established and reproductively active population in the study area, which presents suitable conditions for $P$. clarkii to proliferate. In addition, our results demonstrated that the marsh showed better conditions than the lake for growth of crayfish individuals within the study area.

\section{Impacts and implications for population control}

The Nature Reserve of the Lago di Candia is a circumscribed area rich in biodiversity and identified both as a Natura 2000 Network SCI and SPA. As suggested by many studies (Gherardi et al., 2011; Nunes et al., 2017) and confirmed by our results, complete eradication of red swamp crayfish is probably impossible to achieve. In any case, it is fundamental to limit the invasion of $P$. clarkii, which is a real threat to the protected area, in order to reduce the negative impacts of the species on the biodiversity of the site. Moreover, reduction in macrophyte biomass and survival has already been recorded in a Dutch peat lake, where $P$. clarkii was expanding rapidly (van der Wal et al., 2013). Surveys carried out in 2011 and in 2015 indicated that some macrophyte 
species, which were previously present in the lake disappeared over a 4-year period (e.g. Najas marina and Nymphoides peltata). Some other species showed a dramatic decrease of their occupied surface, e.g. Myriophyllum spicatum lost $98.5 \%$ and Trapa natans lost 87\% (CNR and ARPA Piemonte; unpublished data). The influence of $P$. clarkii on macrophyte communities and biomass are well-known and described, not only due to the direct consumption, but also by non-consumptive cutting of the stems (Nyström and Strand, 1996, Gherardi, 2006; Loureiro et al., 2015).

Trapping for mechanical removal is a widespread method for managing $P$. clarkii populations in natural environments. Trapping is considered to work well on huge target populations and to be highly efficient. However, this efficacy is only achieved if trapping activities are conducted for an extended period of time and with regularity, which require intensive manpower and involve high costs. Moreover, the use of net traps shows high selectivity, as it can affect specific classes of individuals in the target population and lacks speciesspecificity (Gherardi et al., 2011). The results of our study suggest that baited net traps were an efficient way to easily capture and remove large amounts of crayfish individuals from a huge target population. However, traps are affected by the size of individuals due to many factors, the first of which is the mesh size, resulting in higher trappability of larger crayfish. This can have various implications that should be evaluated. Firstly, larger females generally produce more eggs than smaller females; moreover, their eggs have greater weight and volume, factors that result in a greater reproductive output (Gutiérrez-Yurrita and Montes, 1999; Alcorlo et al., 2008). Therefore, removal of larger females could be more beneficial in controlling future generations. However, this kind of selection could also lead to feedback mechanisms with consequent increase of egg production and earlier maturity in females (Holdich et al., 1999). In addition, we suggest that removing large individuals could reallocate the environmental resources to the remaining part of the population and therefore to smaller individuals too. Liberation of resources and space could eventually lead to the arrival of adult individuals from adjacent areas (Gherardi et al., 2011). All these factors could explain the results of our study. Moreover, we argue that the trapping activities carried out in 2014 were efficient, but not adequately extended over time. Some studies show that trapping activities can be highly effective in reducing the size of a population but, in the absence of continuity, populations rapidly return to their former levels (Rogers et al., 1997; Holdich et al., 1999). Therefore, we highlight that massive removals of the species should be performed during the entire period of activity in the study area, and that it is important to consider more than just 1 year of trapping activities, as also suggested by Nunes et al. (2017). Continued trapping is thus preferred to intensive short-term trapping (Loureiro et al., 2015). In the case of future massive catches, we think it would be useful to use nets as well as fyke-nets in the connecting area between the lake and the marsh, in order to increase trapping success. Indeed, the water channels that connect the two habitats are probably an important passage for P. clarkii, and therefore a strategic position to intercept the crayfish. For the same reason, nets should also be placed in the outgoing streams surrounding the protected area, as these channels could be a pathway for the arrival of new individuals. Reintroduction or restocking of indigenous predators (Esox lucius and Anguilla anguilla) could also be considered in the perspective of $P$. clarkii population management in the study area. As suggested by Aquiloni et al. (2010), the presence of a predator such as the European eel, combined with trapping, may be effective against invasive populations of crayfish. Of course, these actions require accurate feasibility studies to assess their potential for implementation in the area. Finally, we underline the importance of early detection in sites that are potentially suitable for the invasion by $P$. clarkii. To this end, it is important to raise the awareness of local populations, which also aims at reducing the additional spread of the species caused by further liberation of individuals in natural environments. The problems related to the presence of $P$. clarkii are already explained and discussed with visitors and students who frequent the protected area.

Recently $P$. clarkii has been included in the recent "Union List" of invasive alien species of union relevance (implementing regulation EU 2016/1141) by European Union Member States. Therefore, in order to implement an appropriate management plan of these species, the EU Regulation 1143/2014, Article 19 and Article 20, provide guidelines for management measures and restoration of damaged ecosystems. In particular, commercial exploitation of invasive alien species already present can be temporally authorized under management measures for eradication, population control or confinement, but only if strictly justified. Nowadays, the different methods applied to control or reduce populations include mechanical removal; physical methods like drainage of ponds or construction of barriers (Dana et al., 2011); biocontrol, which takes advantage of the natural enemies of the species in question (Aquiloni et al., 2010); pesticides or biocides (Gherardi et al., 2011); and autocidal methods such as sex pheromones or sterile males release technique (SMRT; Aquiloni et al., 2009; Aquiloni and Gherardi, 2010). Moreover, European Member States should engage restoration measures to rebuild ecosystems which have been degraded, damaged or destroyed by invasive species.

Acknowledgements. Vivere $i$ Parchi A.P.S. was partially funded for the field activities by the Città Metropolitana di Torino and by the Regione Piemonte, under the Piano di Sviluppo Rurale (PSR) 2007-2013 (measure 323) for the realization of the Valutazione ed incremento della Biodiversità all'interno della Rete Ecologica Provinciale project. We would like to thank the Città Metropolitana di Torino and in particular Dr. Gabriele Bovo and Dr. Alessandra Pucci. We would also like to thank the Agenzia Regionale per la Protezione Ambientale (ARPA), the Istituto Zooprofilattico Sperimentale del Piemonte Liguria e Valle D'Aosta (IZSTO) and in particular Dr. Marino Prearo. We are grateful to the Volunteer Ecological Guards for their help in sampling activities; Emily Collins for her help in the translation of a first draft of the manuscript and Radhika Srinivasan (MedSTEd) for the linguistic revision; and two anonymous reviewers for their valuable comments.

\section{References}

Adão H, Marques JC. 1993. Population biology of the Red Swamp Crayfish Procambarus clarkii (Girard, 1852) in Southern Portugal. Crustaceana 65: 336-345. 
Aiken DE. Molting and growth. In: Cobb JS, Phillips BF, eds. The Biology and Management of Lobsters. Sidney: Academic Press, 1980, pp. 91-163.

Alcorlo P, Geiger W, Otero M. 2008. Reproductive biology and life cycle of the invasive crayfish Procambarus clarkii (Crustacea: Decapoda) in diverse aquatic habitats of South-Western Spain: implications for population control. Fundam Appl Limnol 173: 197-212.

Anastácio PM, Marques JC. 1995. Population biology and production of the red swamp crayfish Procambarus clarkii (Girard) in the lower Mondego river valley, Portugal. J Crustac Biol 15: 156-168.

Anastácio PM, Marques JC. 1998. Crayfish (Procambarus clarkii) condition throughout the year in the Lower Mondego River Valley, Portugal. Crustaceana 71: 593-602.

Aquiloni L, Gherardi F. 2010. The use of sex pheromones for the control of invasive populations of the crayfish Procambarus clarkii: a field study. Hydrobiologia 649: 249-254.

Aquiloni L, Ilhéu M, Gherardi F. 2005. Habitat use and dispersal of the invasive crayfish Procambarus clarkii in ephemeral water bodies of Portugal. Mar Freshw Behav Physiol 38: 225-236.

Aquiloni L, Becciolini A, Berti R, Porciani S, Trunfio C, Gherardi F. 2009. Managing invasive crayfish: using X-ray sterilization of males. Freshw Biol 54: 1510-1519.

Aquiloni L, Brusconi S, Cecchinelli E, Tricarico E, Mazza G, Paglianti A, Gherardi F. 2010. Biological control of invasive populations of crayfish: the European eel (Anguilla anguilla) as a predator of Procambarus clarkii. Biol Invasions 12: $3817-$ 3824.

Banha F, Anastácio PM. 2014. Desiccation survival capacities of two invasive crayfish species. Knowl Manag Aquat Ecosyst 413: 01.

Barbaresi S, Santini G, Tricarico E, Gherardi F. 2004. Ranging behaviour of the invasive crayfish, Procambarus clarkii (Girard). $J$ Nat Hist 38: 2821-2832.

Bissattini A, Traversetti L, Bellavia G, Scalici M. 2015. Tolerance of increasing water salinity in the red swamp crayfish Procambarus clarkii (Girard, 1852). J Crustac Biol 35: 682-685.

Breithaupt T, Schmitz B, Tautz J. 1995. Hydrodynamic orientation of crayfish (Procambarus clarkii) to swimming fish prey. J Comp Physiol A 177: 481-491.

Chiesa S, Scalici M, Gibertini G. 2006. Occurrence of allochthonous freshwater crayfishes in Latium (Central Italy). Knowl Manag Aquat Ecosyst 380: 883-902.

Chiesa S, Scalici M, Lucentini L, Nonnis MF. 2014. Molecular identification of an alien temnocephalan crayfish parasite in Italian freshwaters. Aquat Invasion 10: 209-216.

Correia AM. 2001. Seasonal and interspecific evaluation of predation by mammals and birds on the introduced red swamp crayfish Procambarus clarkii (Crustacea, Cambaridae) in a freshwater marsh (Portugal). J Zool 255: 533-541.

Correia AM, Ferreira Ó. 1995. Burrowing behavior of the introduced red swamp crayfish Procambarus clarkii (Decapoda: Cambaridae) in Portugal. J Crustac Biol 15: 248-257.

Cruz MJ, Rebelo R. 2007. Colonization of freshwater habitats by an introduced crayfish, Procambarus clarkii in Southwest Iberian Peninsula. Hydrobiologia 575: 191-201.

DAISIE European Invasive Alien Species Gateway. 2017. Procambarus clarkii. http://www.europe-aliens.org/speciesFactsheet.do? speciesId $=53452$ (Accessed 18th September 2017)

Dana ED, García-de-Lomas J, González R, Ortega F. 2011. Effectiveness of dam construction to contain the invasive crayfish Procambarus clarkii in a Mediterranean mountain stream. Ecol Eng 37: 1607-1613.
Delmastro GB. 2017. Il gambero della Louisiana Procambarus clarkii (Girard 1852) in Piemonte: nuove osservazioni su distribuzione, biologia, impatto ed utilizzo (Crustacea: Decapoda: Cambaridae). Rivista piemontese di storia naturale 38: 61-129.

Dörr AJM, La Porta G, Pedicillo G, Lorenzoni M. 2006. Biology of Procambarus clarkii (Girard, 1852) in Lake Trasimeno. Bull Fr Peche Piscic 380: 1155-1168.

Dörr AJM, Rodolfi M, Scalici M, Elia AC, Garzoli L, Picco AM. 2011. Phoma glomerata, a potential new threat to Italian inland waters. J Nat Conserv 19: 370-373.

Dörr AJM, Elia AC, Rodolfi M, et al. 2012a. A model of cooccurrence: segregation and aggregation patterns in the mycoflora of the crayfish Procambarus clarkii in Lake Trasimeno (central Italy). J Limnol 71: 135-143.

Dörr AJM, Rodolfi M, Elia AC, Scalici M, Garzoli L, Picco AM. 2012b. Mycoflora on the cuticle of the invasive crayfish Procambarus clarkii. Fund Appl Limnol 180: 77-84.

Dörr AJM, Scalici M. 2013. Revisiting reproduction and population structure and dynamics of Procambarus clarkii eight years after its introduction into Lake Trasimeno (Central Italy). Knowl Manag Aquat Ecosyst 408: 10.

European Union. 2014. Regulation 1143/2014 of the European Parliament and of the Council of 22 October 2014 on the prevention and management of the introduction and spread of invasive alien species. Off J Eur Union L 317: 35.

European Union. 2016. Commission implementing regulation 2016/ 1141 of 13 July 2016 adopting a list of invasive alien species of Union concern pursuant to Regulation (EU) No 1143/2014 of the European Parliament and of the Council. Off J Eur Union L 189: 4.

Fagerland MW. 2012. T-tests, non-parametric tests, and large studies - a paradox of statistical practice? BMC Med Res Methodol 12: 78.

Favaro L, Tirelli T, Pessani D. 2010. The role of water chemistry in the distribution of Austropotamobius pallipes (Crustacea Decapoda Astacidae) in Piedmont (Italy). C R Biol 333: 68-75.

Favaro L, Tirelli T, Gamba M, Pessani D. 2011a. Sound production in the red swamp crayfish Procambarus clarkii (Decapoda Cambaridae). Zool Anz 150: 143-150.

Favaro L, Tirelli T, Pessani D. 2011b. Modelling habitat requirements of white-clawed crayfish (Austropotamobius pallipes) using support vector machines. Knowl Manag Aquat Ecosyst 401: 21.

Faxon W. 1884. Descriptions of new species of Cambarus, to which is added a synonymical list of the known species of Cambarus and Astacus. Proc American Acad Arts Sci 20: 107-158.

Fidalgo MRA, Carvalho P, Santos P. 2001. Population dynamics of the red swamp crayfish, Procambarus clarkii (Girard, 1852) from the Averio Region, Portugal (Decapoda, Cambaridae). Crustaceana 74: 369-375.

Gherardi F. 2006. Crayfish invading Europe: the case study of Procambarus clarkii. Mar Freshw Behav Physiol 39: 175-191.

Gherardi F, Barbaresi S. 2000. Invasive crayfish: activity patterns of Procambarus clarkii in the rice fields of the Lower Guadalquivir (Spain). Arch Hydrobiol 150: 153-168.

Gherardi F, Cioni A. 2004. Agonism and interference competition in freshwater decapods. Behaviour 141: 1297-1324.

Gherardi F, Barbaresi S, Salvi G. 2000. Spatial and temporal patterns in the movement of Procambarus clarkii, an invasive crayfish. Aquat Sci 62: 179-193.

Gherardi F, Aquiloni L, Diéguez-Uribeondo J, Tricarico E. 2011. Managing invasive crayfish: is there a hope? Aquat Sci 73: 185-200.

Gherardi F, Renai B, Corti C. 2001. Crayfish predation on tadpoles: a comparison between a native (Austropotamobius pallipes) and an alien species (Procambarus clarkii). Bull Fr Peche Piscic 361: 659-668. 
Gherardi F, Tricarico E, Ilhéu M. 2002. Movement patterns of an invasive crayfish, Procambarus clarkii, in a temporary stream of Southern Portugal. Ethol Ecol Evol 14: 183-197.

Gutiérrez-Yurrita PJ, Montes C. 1999. Bioenergetics and phenology of reproduction of the introduced red swamp crayfish, Procambarus clarkii, in Doñana National Park, Spain, and implications for species management. Freshw Biol 42: 561-574.

Gutiérrez-Yurrita PJ, Martínez JM, Bravo-Utrera MÁ, Montes C, Ilhéu M, Bernardo JM. 1999. The status of crayfish populations in Spain and Portugal. In Gherardi F, Holdich DM, eds. Crayfish in Europe as alien species. How to make the best of a bad situation? Rotterdam: A.A. Balkema, pp. 161-192.

Heck KL Jr, Crowder LB. 1991. Habitat structure and predator-prey interactions in vegetated aquatic system. In Bell SS, McCoy ED, Mushinsky KR, eds. Habitat structure, population and community biology series, vol 8. Dordrecht: Springer, pp. 281-299.

Hobbs HH Jr. 1972. Crayfishes (Astacidae) of North and Middle America. In: Biota of freshwater ecosystems, identification manual 9, Water pollution control research series. Washington DC: US environmental protection agency.

Holdich DM, Gydemo R, Rogers WD. 1999. A review of possible methods for controlling nuisance populations of alien crayfish. In: Gherardi F, Holdich DM, eds. Crayfish in Europe as alien species. How to make the best of a bad situation? Rotterdam: A.A. Balkema, pp. 245-270.

Huner JV. 1977. Introductions of the Louisiana red swamp crayfish, Procambarus clarkii (Girard): an update. Freshwater Crayfish 3: 193-202.

Huner JV. 1978. Observation on the life histories of recreationally important crawfish in temporary habitats. La Acad Sci 38: 20-24.

Huner JV. 2002. Procambarus. In: Holdich DM, ed. Biology of freshwater crayfish. Oxford, UK: Blackwell, pp. 541-584.

Huner JV, Avault JW Jr. 1979. Introductions of Procambarus spp. Freshw Crayfish 4: 191-194.

Ilhéu M, Bernardo JM, Fernandes S. 2007. Predation of invasive crayfish on aquatic vertebrates: the effect of Procambarus clarkii on fish assemblages in Mediterranean temporary streams. In: Gherardi F, ed. Biological invaders in inland waters: profiles, distribution, and threats. The Netherlands: Springer Dordrecht, pp. 543-558.

Jordan F, Babbitt KJ, McIvory CC, Miller SJ. 1996. Spatial ecology of the crayfish Procambarus alleni in a Florida wetland mosaic. Wetlands 16: 134-142.

Kouba A, Tíkal J, Císař P, et al. 2016. The significance of droughts for hyporheic dwellers: evidence from freshwater crayfish. Sci Rep 6: 26569.

Lereboullet A. 1858. Descriptions de deux nouvelles especes d'ecrevisses de nos rivieres. Memoirs de la Societe des Sciences Naturelles de Strasbourg 5: 1.

Ligas A. 2008. Population dynamics of Procambarus clarkii (Girard, 1852) (Decapoda, Astacidea, Cambaridae) from Southern Tuscany (Italy). Crustaceana 81: 601-609.

Loureiro TG, Anastácio PMSG, Araujo PB, Souty-Grosset C, Pereira AM. 2015. Red swamp crayfish: biology, ecology and invasion an overview. Nauplius 23: 1-19.

Maccarone V, Filiciotto F, Buffa G, et al. 2016. An invasive species in a protected area of Southern Italy: the structure, dynamics and spatial distribution of the crayfish Procambarus clarkii. TurkJ Fish Aquat Sc 16: 401-412.
Mazzoni D, Gherardi F, Ferrarini P. 2004. Guida al riconoscimento dei gamberi d'acqua dolce, 2nd edn. Bologna: Greentime SpA, 34 p.

Nunes AL, Hoffman AC, Zengeya TA, Measey GJ, Weyl OLF. 2017. Red swamp crayfish, Procambarus clarkii, found in South Africa 22 years after attempted eradication. Aquat Conserv Mar Freshw Ecosyst 27: 1334-1340.

Nyström P, Strand JA. 1996. Grazing by a native and an exotic crayfish on acquatic macrophytes. Freshw Biol 36: 673-682.

Oluoch AO. 1990. Breeding biology of the Louisiana red swamp crayfish Procambarus clarkii Girard in Lake Naivasha, Kenya. Hydrobiologia 208: 85-92.

Paglianti A, Gherardi F. 2004. Combined effects of temperature and diet on growth and survival of YOY crayfish: a comparison between indigenous and invasive species. J Crustac Biol 24: 140-148.

Penn GH. 1943. A study of the life history of the Louisiana redswamp crawfish, Cambarus clarkii Girard. Ecology 24: 1-18.

Ramalho RO, Correia AM, Anastácio PM. 2008. Effects of density on growth and survival of juvenile Red swamp crayfish, Procambarus clarkii (Girard), reared under laboratory conditions. Aquac Res 39: 577-586.

Renai B, Gherardi F. 2004. Predatory efficiency of crayfish: comparison between indigenous and nonindigenous species. Biol Invasions 6: 89-99.

Reynolds JD. 2002. Growth and reproduction. In: Holdich DM, ed. Biology of freshwater Crayfish. Oxford, UK: Blackwell Science, pp. 152-191.

Ricker WE. 1975. Computation and interpretation of biological statistics of fish populations. Bull Fish Res Board Can 191: 1-382.

Rogers WD, Holdich DM, Carter E. 1997. Crayfish eradication. Peterborough: Report for English Nature.

Savini D, Occhipinti AA, Nicolao J, et al. 2008. Il Gambero invasivo Procambarus clarkii (Girard, 1852) nella Lanca della Riserva Naturale Integrale "Bosco Siro Negri". Archivio Geobotanico 11: $49-58$.

Scalici M, Gherardi F. 2007. Structure and dynamics of an invasive population of the red swamp crayfish (Procambarus clarkii) in a Mediterranean wetland. Hydrobiologia 583: 309-319.

Scalici M, Chiesa S, Scuderi S, Celauro D, Gibertini G. 2010. Population structure and dynamics of Procambarus clarkii (Girard, 1852 ) in a Mediterranean brackish wetland (Central Italy). Biol Invasions 12: 1415-1425.

Schikora F. 1906. Die Krebspest. Fischerei-Zeitung 9: 529-532.

Sokal RR, Rohlf FJ. 1995. Biometry: the principles and practice of statistics in biological research, 3rd edn. New York: Freeman WH and Company, $887 \mathrm{p}$.

Souty-Grosset C, Anastácio PM, Aquiloni L, et al. 2016. The red swamp crayfish Procambarus clarkii in Europe: impacts on aquatic ecosystems and human well-being. Limnologica 58: 78-93.

Tirelli T, Favaro L, Gamba M, Pessani D. 2011. Performance comparison among multivariate and data mining approaches to model presence/absence of Austropotamobius pallipes complex in Piedmont (North Western Italy). C R Biol 334: 695-704.

van der Wal JEM, Dorenbosch M, Immers AK, et al. 2013. Invasive crayfish threaten the development of submerged macrophytes in lake restoration. PLoS One 8: 1-11.

Vogt G. 2013. Abbreviation of larval development and extension of brood care as key features of the evolution of freshwater Decapoda. Biol Rev 88: 81-116.

Cite this article as: Donato R, Rollandin M, Favaro L, Ferrarese A, Pessani D, Ghia D. 2018. Habitat use and population structure of the invasive red swamp crayfish Procambarus clarkii (Girard, 1852) in a protected area in northern Italy. Knowl. Manag. Aquat. Ecosyst., 419, 12. 